\title{
The Adaptation Of Multidimensional State Boredom Scale Into Turkish
}

\author{
Ümmügülsüm Korkmaz* \\ Yrd. Doç. Dr., Osmangazi Üniversitesi,ukorkmaz@ogu.edu.tr
}

\section{Merve Nur Şahan}

Afyon Kocatepe Üniversitesi mngirgin@aku.edu.tr

\begin{abstract}
The purpose of this study was to adapt Multidimensional State Boredom Scale developed by Fahlman, Mercer-Lynn, Flora and Eastwood (2013) into Turkish language and culture. The scale was applied to a total of 305 students attending Afyon Kocatepe University in Turkey. After Confirmatory Factor Analysis was conducted for testing construct validity, it was determined that the adapted scale consisted of 27 items and five factors (Disengagement, High-Arousal, Low-Arousal, Inattention, TimePerception). The internal consistency coefficient was found as .91 for the whole scale. According to the results obtained through the study, Turkish version of Multidimensional State Boredom Scale is an instrument that can be used in the assessment of boredom proneness.
\end{abstract}

Keywords: Boredom proneness, Turkish, adaptation, validity, reliability

Citation: Korkmaz, Ü., \& Şahan, M. N. (2016). The Adaptation Of Multidimensional State Boredom Scale Into Turkish. Anatolian Journal of Education, 1(1), 33-50. https://doi.org/10.29333/aje.2016.113a

* Corresponding author 


\section{Çok Boyutlu Can Sıkıntısı Eğilimi Ölçeğinin Türkçe'ye Uyarlanması}

Bu çalışmanın amacı Fahlman, Mercer-Lynn, Flora ve Eastwood (2013) tarafından geliştirilen Çok boyutlu Can Sıkıntısı Eğilimi Ölçeği’ni Türk diline ve kültürüne uyarlamaktır. Ölçek maddelerinin çevirme-geri çevirme yöntemi ile çevirisi yapıldıktan sonra çevrimiçi olarak oluşturulan ölçek Afyon Kocatepe Üniversitesi'nde eğitim gören 305 öğrenciye uygulanmıştır. Doğrulayıcı Faktör Analizi sonuçlarına göre testin 27 madde ve 5 faktör (İlişki Kesme, Yüksek Uyarılma, Düşük Uyarılma, Dikkat Etmemek, Zaman Algısı) olarak kullanılmasına karar verilmiştir. Tüm ölçek için iç tutarlılık güvenirlik değeri .91 olarak bulunmuştur. Çalışma sonuçlarına göre, Çok Boyutlu Can Sıkıntısı Eğilimi Ölçeği’nin Türkçe versiyonunun psikometrik özellikleri bu ölçeğin can sıkıntısı eğilimini ölçmek için kullanılabileceğini göstermiştir.

Anahtar Kelimeler: Can sıkıntısı eğilimi, Türkçe, uyarlama, geçerlilik, güvenirlik

\section{INTRODUCTION}

Boredom has been one of the most common feelings experienced in everyday life across all cultures in the world. Although it is common and has been the subject of scientific interest of various fields of study, there is no specific definition accepted universally since the reason of this feeling cannot be known completely. Boredom is defined as 'the experience of being disengaged from the world and stuck in a seemingly endless and dissatisfying present' (Mercer-Lynn, Flora, Fahlman, \& Eastwood, 2011, s. 1). On the other hand, Vodanovich defined boredom as a personality trait which is similar to impulsiveness, neuroticism and extraversion rather than a state derived from monotonous situational factors (Vodanovich, 2003). Boredom might be a temporary feeling which stems from dissatisfaction of a situation or might be a permanent feeling that is experienced in all situations as if it is a part of personal trait. Besides its being a temporary or permanent feeling, its serious effects on different fields is observed clearly. Boredom may cause significant problems for individuals in areas from education or health to socialization and so on. Additionally, it may lead to severe outcomes such as dropping out of school, gambling, drug or alcohol abuse, depression, anxiety, eating or psychological disorders, overeating and binge eating (Eastwood, Cavaliere, Fahlman, \& Eastwood, 2007; Mann \& Robinson, 2009; Mercer \& Eastwood, 2010; LePera, 2011). Moreover, boredom is associated with lower psychological well-being such as dissatisfaction with life or job, lower levels of life meaning and even death (Alda et. al, 2015). 
There have been many studies in the literature conducted on boredom itself and its relation with anger, anxiety, personality, psychological well-being, neuroticism, and other subjects (Watt \& Vodanovich, 1999; MacDonald \& Holland, 2012; Barnett \& Klitzing, 2006; Shaw, 1996; Weissinger, 1995). However, when it comes to measuring boredom, not many scales can be found. In order to measure boredom proneness of individuals, there were some sub-scales of inventories and main scales that were developed. There are two commonly used scales measuring boredom: Farmer and Sundberg's Boredom Proneness Scale (BPS) and the Boredom Susceptibility Scale (BSS), which is the subscale of Zuckerman's Sensation Seeking Scale. Farmer and Sundberg developed Boredom Proneness Scale in true-false format in order to address the need measuring general construct of boredom. Since BPS's development, various factor analysis studies have been conducted. Ahmed (1990) conducted an exploratory factor analysis and found two constructs: apathy and inattention. On the other hand, Vodanovich and Kass (1990) carried out EFA by using 7-point Likert type format and found five factors called as external stimulation, internal stimulation, affective responses, perception of time and constraint. Even though BPS and BSS was thought to measure the same construct, Mercer-Lynn and colleugues have found that higher BPS scores were related to higher levels of neuroticism, depression, experiential avoidance, and anxiety. In contrast, higher BSS scores were associated with higher levels of gambling, alcohol use, motor impulsivity, sensitivity to reward and lower level of neuroticism, experiential avoidance, and sensitivity to punishment (Mercer-Lynn, Flora, Fahlman, \& Eastwood, 2011).

In further research, Vodanovich, Wallace and Kass omitted some items from BPS after some factor analyses studies and developed a short form of it with two subscales consisting of 6 items for internal stimulation and 6 items for external stimulation (Vodanovich, Wallace, \& Kass, 2005). Turkish adaptation study of BPS-Short Form was conducted and results led to two factors as in the original scale. However, internal consistency coefficients of the two subscales were low (Dursun \& Tezer, 2013). Additionally, Vodanovich and Watt (1999) explained that boredom was mostly related to a concept of time in which individuals did not have meaningtful activities to participate in their leisure times. Likewise, Iso-Ahola and Weissinger (1990) developed Leisure Boredom Scale (LBS) to evaluate the perception of boredom in leisure times. LBS has one dimension and consists of 16 items. LBS has been used in many studies so as to analyze the relationships between perceived boredom in leisure times and alcohol use, personality, internet addiction, school dropout, drug abuse, depression and suicidal issues (Wegner, Flisher, Muller, \& Lombard, 2006; Wegner \& Flisher, 2009; Patterson, Pegg, \& Dobson-Patterson, 1999; Lin, Lin, \& Wu, 2009; Belton \& Priyadharshini 2007; Iso-Ahola \& Crowley; 1991). Turkish adaptation study of Leisure Boredom Scale was 
conducted and items were found to be valid in Turkish version, as well (Kara, Gürbüz, \& Öncü, 2014). There are also scales aiming at measuring boredom such as Job Boredom Scale (Lee, 1986), Sexual Boredom Scale (Watt \& Ewing, 1996) and Free Time Boredom Scale (Ragheb \& Merydith, 2001). However, all of these scales lack efficacy since they focus on boredom in a particular context such as sexual relations, free time or job environment. Except for BSS and BPS, these scales on boredom in fact have received little attention in the literature.

With the aim of expanding the measurement of boredom, Fahlman and colleugues (2013) developed a new model called Multidimensional State Boredom Scale (MSBS): the scale aimed at measuring boredom felt both at the time being and in general. The scale consists of five factors which are disengagement, high arousal, low arousal, inattention and time perception. The results of the study showed that MSBS scores were well-correlated with measures of life satisfaction, neuroticism, depression, anger, anxiety, and purpose in life (Fahlman, Mercer-Lynn, Flora, \& Eastwood, 2013).

Boredom is a common problem experienced in all societies around the world and it may lead to many serious psychological problems or disorders if necessary importance is not given to this feeling. In Turkey, boredom has been a problem experienced widely by individuals of all ages. However, the scales that are present in Turkish have not been used yet. Thus, an updated version of scales aiming at measuring boredom proneness of individuals is needed. Adapting MSBS into Turkish will help researchers study and measure boredom proneness of the individuals in Turkey. Studying this subject may enable researchers to reach the individuals who experience boredom in a problematic level and to prevent possible serious outcomes.

\section{METHOD}

\section{Participants}

Participants were selected through randomized cluster sampling. The cluster was the school. The sampling was all the students studying at Afyon Kocatepe University in Turkey. Students studying in the Faculty of Economics and Administrative Sciences were selected since they constitute the majority of the college. However, some students from other faculties participated voluntarily in our study, as well. A total of 305 students (128 males and 177 females) filled out the questionnaire online. Participants studied in the departments of Economics (18.7\%), Business Administration (28.2 \%), International Trade and Finance (46.9\%), Engineering (4.6\%) and others (1.6\%). Of the 305 participants, $9.8 \%$ were attending preparatory class, $50.2 \%$ were freshman, 1.2 
$\%$ were sophomore, $1 \%$ were junior, $36.1 \%$ were senior students and $\% 1.3$ were undergraduate and suspension students. Of the 305 participants, 18 was from Black Sea Region, 104 was from Aegean Region, 34 was from Mediterranean Region, 62 was from Marmara Region, 60 was from Central Anatolia Region, 7 was from Eastern Anatolia Region, 16 was from Southeastern Anatolia Region and 4 was from other countries (Russia, Azerbaijan, Turkmenistan).

\section{Data Collection Tools}

The Personal Information Form: This form was developed by the conductors of the study so as to gather information about the participants related to independent variables such as their gender, department in which they study, their grades and hometowns. With the hometowns, we would know how disperse the sample was.

Multidimensional State Boredom Scale (MSBS): The original scale was developed by Fahlman et.al. (2013) so as to examine the boredom proneness in a broad scope both in general and at the time of filling the scale. MSBS was figured in fivedimensional-structure (Disengagement, High Arousal, Low Arousal, Inattention and Time Perception) and it consisted of 29 items. The responses were rated from one to seven in 7-point Likert type ranging from (1) 'strongly disagree' to (7) 'strongly agree'. MSBS was applied to different undergraduate students for four different studies aiming at creating items, analyzing initial item pool, increasing the number of items and validating the final version of the scale. The original scale had .97 for CFI score and .067 for RMSEA score. The Cronbach Alpha reliability coefficient was .87 for disengagement, .85 for high-arousal, .86 for low-arousal, .80 for inattention, .88 for time perception and .94 for the scores of the full scale.

\section{The Translation-Adaptation Procedure}

The necessary permission of the scale developers was received before the Turkish adaptation procedure. During the adaptation process, translation and back translation methods were used. The scale was first translated into Turkish by three independent translators who work as English Language Instructors in different state and private universities: each completed translation separately. Later on, the Turkish translations were sent to another three instructors of English Language working at School of Foreign Languages in both state and private universities for back-translation. Three backtranslated versions of the scale were compared with the Turkish translated versions to provide consistency in meaning for items of each scale with those of the original scale. Items were chosen by the researchers to assure whether the meaning of each item was maintained. 


\section{Pilot Study}

The final version of the scale was pretested for the clarity of the items by applying on a small random sample of pilot subjects $(n=42)$. The scale was well received and participants did not report any problems in responding the items. The Cronbach Alpha reliability coefficient was .918 for the scores of 29 items from the pilot study. All of the 29 items were included to the main adaptation study. After all these procedure, the adapted Multidimensional State Boredom Scale was made ready to test psychometric properties.

\section{Procedure}

Before the application of the scale, necessary explanations about the goal of the study and how to fill out the instrument were given. The researchers informed the students that their participation was voluntary, anonymous and confidential and their answers would be used for scientific purposes. The participants filled out the forms online. The application process took 4 to 15 minutes for 305 participants. Data was collected within 2 weeks during 2016 Spring semester.

\section{Results}

First, the descriptive statistics (mean, variance, standard deviatons, skweness, and kurtosis) were calculated for each items by using the statistical package IBM SPSS 21. Kurtosis of the 29 items were between 2.115 to -1.1315 . LISREL Statistical package was used to apply Confirmatory Factor Analysis. Robust Maximum Likelihood was used.

Table 1

Descriptive Statistics of the 29 items

\begin{tabular}{llllllll}
\hline & $\mathrm{N}$ & Mean & SD & Skewness & & Kurtosis \\
& & & & Statistic & Std. Error & Statistic & Std. Error \\
\hline item1 & 305 & 4.00 & 1.687 & -.076 & .140 & -1.065 & .278 \\
item2 & 305 & 3.83 & 1.686 & .157 & .140 & -.952 & .278 \\
item3 & 305 & 2.72 & 1.681 & 1.060 & .140 & .361 & .278 \\
item4 & 305 & 4.40 & 1.760 & -.451 & .140 & -.855 & .278
\end{tabular}




\begin{tabular}{|c|c|c|c|c|c|c|c|}
\hline item5 & 305 & 3.93 & 1.894 & .004 & .140 & -1.072 & .278 \\
\hline item6 & 305 & 4.22 & 1.968 & -.297 & .140 & -1.249 & .278 \\
\hline item7 & 305 & 3.01 & 1.876 & .896 & .140 & -.234 & .278 \\
\hline item8 & 305 & 3.68 & 1.866 & .303 & .140 & -1.028 & .278 \\
\hline item9 & 305 & 3.88 & 1.926 & .116 & .140 & -1.189 & .278 \\
\hline item10 & 305 & 3.19 & 1.845 & .752 & .140 & -.466 & .278 \\
\hline item 11 & 305 & 4.16 & 1.741 & -.235 & .140 & -1.101 & .278 \\
\hline item 12 & 305 & 4.05 & 1.962 & -.017 & .140 & -1.213 & .278 \\
\hline item13 & 305 & 3.66 & 1.894 & .358 & .140 & -1.006 & .278 \\
\hline item14 & 305 & 3.76 & 1.844 & .261 & .140 & -1.089 & .278 \\
\hline item 15 & 305 & 4.26 & 1.715 & -.359 & .140 & -.849 & .278 \\
\hline item16 & 305 & 3.19 & 1.790 & .745 & .140 & -.445 & .278 \\
\hline item17 & 305 & 3.92 & 1.889 & .016 & .140 & -1.162 & .278 \\
\hline item 18 & 305 & 4.33 & 1.811 & -.383 & .140 & -1.050 & .278 \\
\hline item19 & 305 & 2.25 & 1.559 & 1.616 & .140 & 2.115 & .278 \\
\hline item20 & 305 & 3.36 & 1.867 & .715 & .140 & -.653 & .278 \\
\hline item 21 & 305 & 3.79 & 1.971 & .225 & .140 & -1.154 & .278 \\
\hline item 22 & 305 & 3.01 & 1.864 & .822 & .140 & -.397 & .278 \\
\hline item 23 & 305 & 3.18 & 1.864 & .804 & .140 & -.475 & .278 \\
\hline item24 & 305 & 3.24 & 1.880 & .542 & .140 & -.865 & .278 \\
\hline item 25 & 305 & 4.48 & 1.698 & -.533 & .140 & -.668 & .278 \\
\hline item 26 & 305 & 4.29 & 1.772 & -.317 & .140 & -1.057 & .278 \\
\hline item 27 & 305 & 4.02 & 1.855 & .040 & .140 & -1.117 & .278 \\
\hline item 28 & 305 & 3.90 & 2.002 & .121 & .140 & -1.315 & .278 \\
\hline item29 & 305 & 4.51 & 1.661 & -.626 & .140 & -.607 & .278 \\
\hline Valid N (listwise) & 305 & & & & & & \\
\hline
\end{tabular}

\section{Reliability}


Reliabilty was calculated by using SPSS 21. Turkish version of the MSBS indicated the same factorial structure as in the original. The sub-dimensions of the adapted intrument are disengagement, high arousal, low arousal, inattention and time perception. The Cronbach Alpha reliability coefficient was .80 for disengagement, .68 for high-arousal, .78 for low-arousal, .80 for inattention, .88 for time perception and .91 for the full scale for the sample of the present study. The Tukey's Test for Nonadditivity is .169 suggesting that no multiplicative interaction between the items and the cases was found.

\section{Validity}

With the intention of confirming factors existing in the original scale, Confirmatory Factor Analysis was performed for the construct validity using LISREL. Missing data, outliers and normality of the data set were checked before the analysis. After the analysis, the result presented that the item 2 had a low factor loading (.21). Additionally, modification indices suggest to add the path from factors disengagement, high-arousal, and low-arousal to item 23 with expected decrease in Chi-square 28.6, 26.2, and 35.0 respectively. Because of these reasons, both of the item 2 and 23 were eliminated from the questionnaire's Turkish version. In consequence of conducting Confirmatory Factor Analysis, obtained values (CFA I and CFA II - before and after item 2 and 23 were left out) of Goodness of Fit Index (GFI), Adjusted Goodness of Fit Index (AGFI), Root Mean Square of Approximation (RMSEA), Root Mean Square Residuals (RMR), Standardized Root Mean Square Residuals (SRMR), Comparative Fit Index (NNFI), Parsimony Goodness of Fit Index (PGFI) and Parsimony Normed Fit Index(PNFI) were given in Table 2.

Table 2

Results of Confirmatory Factor Analysis

\begin{tabular}{|c|c|c|c|c|}
\hline Measure & Criterion & $\begin{array}{l}\text { Acceptable } \\
\text { Thresholds }\end{array}$ & CFA I & CFA II \\
\hline$x^{2}$ & $\mathrm{p}>0,05$ & - & $\begin{array}{c}644.39 \\
(\mathrm{df}=367 \\
P=0.0)\end{array}$ & $\begin{array}{c}549.01 \\
(\mathrm{df}=314 \\
\mathrm{P}=0.00)\end{array}$ \\
\hline$x^{2} / d f$ & - & $\leq 3=$ perfect fit & 1.75 & 1.74 \\
\hline RMSEA & $\begin{array}{l}0 \text { (perfect fit) } \\
1 \text { (no fit) }\end{array}$ & $\begin{array}{l}\leq 0,05=\text { great fit } \\
\leq 0,08=\text { good fit }\end{array}$ & 0.04 & 0.05 \\
\hline RMR & $\begin{array}{l}0 \text { (perfect fit) } \\
1 \text { (no fit) }\end{array}$ & $\begin{array}{l}\leq 0,05=\text { great fit } \\
\leq 0,08=\text { good fit }\end{array}$ & 0.19 & 0.18 \\
\hline SRMR & $\begin{array}{l}0 \text { (perfect fit) } \\
1 \text { (no fit) }\end{array}$ & $\leq 0,08=\operatorname{good}$ fit & 0.05 & 0.05 \\
\hline$\overline{\text { GFI }}$ & $\begin{array}{l}\text { (no fit) } \\
1 \text { (perfect fit) }\end{array}$ & $\geq 0,90=$ good fit & 0.87 & 0.88 \\
\hline
\end{tabular}




\begin{tabular}{|c|c|c|c|c|}
\hline Measure & Criterion & $\begin{array}{l}\text { Acceptable } \\
\text { Thresholds }\end{array}$ & CFA I & CFA II \\
\hline AGFI & $\begin{array}{l}0 \text { (no fit) } \\
1 \text { (perfect fit) }\end{array}$ & $\geq 0,90=$ good fit & 0.85 & 0.86 \\
\hline NFI & $\begin{array}{l}0 \text { (no fit) } \\
1 \text { (perfect fit) }\end{array}$ & $\geq 0,90=\operatorname{good}$ fit & 0.95 & 0.94 \\
\hline NNFI & $\begin{array}{l}0 \text { (no fit) } \\
1 \text { (perfect fit) }\end{array}$ & $\geq 0,90=$ good fit & 0.98 & 0.97 \\
\hline CFI & $\begin{array}{l}0 \text { (no fit) } \\
1 \text { (perfect fit) }\end{array}$ & $\geq 0,90=$ good fit & 0.98 & 0.97 \\
\hline PGFI & $\begin{array}{l}0 \text { (no fit) } \\
1 \text { (perfect fit) }\end{array}$ & - & 0.73 & 0.73 \\
\hline PNFI & $\begin{array}{l}0 \text { (no fit) } \\
1 \text { (perfect fit) }\end{array}$ & - & 0.86 & 0.84 \\
\hline
\end{tabular}

Note: Criterion and acceptable thresholds were taken from Çokluk, Ö., Şekercioğlu, G., \& Büyüköztürk, Ş. (2010). Sosyal bilimler için çok değişkenli istatistik: SPSS ve LISREL uygulamaları. Ankara: Pegem Akademi, p. 271-272.

Chi-Square value had been $x^{2}=644.39(\mathrm{~N}=305, \mathrm{df}=367, \mathrm{p}=0.00)$ before the item 2 and 23 were eliminated from the instrument. $\mathrm{P}$ value is meaningful because of the large number of sampling. In large number of sampling, where $x^{2} / d f$ value is under 3 , it means perfect level of fit while $x^{2} / d f$ is under 5, it means moderate level of fit (As cited in Kılıç and Şen, 2014). Within this scope, it can be pointed out that $x^{2} / d f$ indicates perfect fit. When goodness of fit index values were analysed, it was observed that both CFA I and CFA II RMSEA values (0.04 and 0.05 respectively) showed perfect level of fit. Standardized RMR values (CFA I=0.05 and CFA $\mathrm{II}=0.05)$ indicated good level of fit.

It can be stated that there was not much difference between the values of CFA I and CFA II. It was seen that Chi-Square value was lower in the second CFA, $x^{2}=549.01$ $(\mathrm{N}=314 \mathrm{df}=367, \mathrm{p}=0.00)$ after item 2 and 23 were eliminated from the scale. New $x^{2} / d f$ value was calculated as $1.74(549.01 / 314)$ and it was not much different from the previous value in CFA I $\left(x^{2} / d f=1.75\right)$. It was found out that PGFI value remained the same and PNFI value decresaed from 0.86 to 0.84 . When all these goodness of fit index values shown in Table 2 are taken into consideration, it can be stated that Turkish version of the MSBS indicates an acceptable level of it.

The path diagram about the CFA I related to Turkish version of the MSBS was indicated in Figure 1 located at the end of the study. It is expected that the item total correlation values should be at least .30 to differentiate the features to be determined (Büyüköztürk, 2007). When factor loadings of concerning model were checked 
according to the findings of CFI I, it was found out that factor loading of item 2 was under .30 as seen in Figure 1. Additionally, modification indices suggest to add the path from factors disengagement, high-arousal, and low-arousal to item 23 with expected decrease in Chi-square 28.6, 26.2, and 35.0, respectively. Item 23 that is apperant in Figure 1 was taken out for the final version.

The path diagram about the CFA II related to final Turkish version of the MSBS was indicated in Figure 2 located at the end of the study. When factor loadings of concerning model were checked according to the findings of CFI II (after item 2 and 23 were excluded), it can be stated that the items on each factor had high loadings on the whole. As it is seen in Figure 2, all factor loads obtained were higher than .30. It was found that item total correlations ranged between .35 and .88 . It can be said that values of 27 items in the scale measure the sub-dimensions forming the overall construct of the MSBS. In other words, factorial validty of the MSBS-Turkish version was assured.

\section{Discussion and Conclusion}

The purpose of current study was to adapt MSBS which was originally developed by Fahlman, et. al (2013) into Turkish. The psychometric properties of the adapted scale were analyzed. Construct validity of the adapted scale was analysed and internal consistency coefficient was examined for the scores' reliability. The construct validty of the scale examined by using Confirmatory Factor Analysis. After conducting CFA, it was found that item 2 had a low factor loading (.21) and modification indices suggested to add the path from factors disengagement, high-arousal, and low-arousal to item 23 with expected decrease in Chi-square 28.6, 26.2, and 35.0 respectively. Therefore, item 2 and 23 were eliminated from the adapted scale. The adapted scale was reanalysed without item 2 and 23 .

In accordance with the results obtained from the analysis, it can be stated that there are not much differences between fit index statistics. It was found that 27 item-scale resulting in 5 factors as in the original was consistent and coherent with the present data. When all the goodness of fit findings are taken into consideration, it can be stated that the relations among data attained from Turkish adapted version assort with theoretical construction. For reliability of the scale, internal consistency coefficent of the full scale and its sub-dimensions were analysed. The Cronbach Alpha reliability coefficient was .80 for Disengagement sub-dimension, .68 for High-Arousal sub-dimension, .78 for Low-Arousal sub-dimension, .80 for Inattention sub-dimension, .88 for Time-Perception sub-dimension and .91 for the whole scale. The Cronbach Alpha coefficient for HighArousal sub-dimension indicates a lower result when compared to other sub-dimensions. Internal consistency coefficient obtained for the whole scale shows parallelism with the 
one calculated in the original scale. Overall, the results support the psychometric properties of the scale in a Turkish sample consisting of undergraduate students.

In conclusion, Turkish version of the MSBS comprises of five factors as in the original instrument. Five-factor model fit the data obtained from the students participating in the study. Internal consistency coefficients of the factors are acceptable. Findings suggest that Turkish version of the MSBS is applicable for assessing the boredom proneness of the individuals.

The adapted version of the items:

\section{Çok boyutlu can sıkıntısı eğilimi ölçeği}

1.Zaman normalde olduğundan daha yavaş geçiyor.

2.Benimle ilgisi olmadığını hissettiğim bir duruma takılıp kalıyorum. (omitted-çıkarıldı)

3.Dikkatim kolayca dağılıyor.

4. Yalnızım.

5.Şu anda her şey bana sinir bozucu geliyor.

6.Keşke zaman daha hızlı geçse.

7.Her şey çok monoton ve rutin gibi geliyor.

8. Keyifsizim.

9.Benim için hiçbir değeri olmayan şeyleri yapmaya zorlanıyormuşum gibi hissediyorum.

10.S1k1liyorum.

11. Zaman geçmek bilmiyor.

12.Normalde olduğumdan daha karamsarım.

13.Bundan sonra ne yapacağım konusunda emin değilim ve karar veremiyorum.

14.Tedirgin hissediyorum.

15.Kendimi bomboş hissediyorum.

16.Dikkatimi toplamakta zorlanıyorum.

17.Eğlenceli bir şeyler yapmak istiyorum ama hiçbir şey ilgimi çekmiyor. 
18.Zaman çok yavaş geçiyor.

19.Daha heyecan verici şeyler yapmayı isterdim.

20.Dikkat sürem normalden daha kısa.

21.Şu anda sabırsızım.

22.Başka bir şey yaparak daha verimli geçirebileceğim zamanımı boşa harcıyorum.

23.Kafam dalgın. (omitted-çıkarıldı)

24.Bir şey olmasını istiyorum ama ne olmasını istediğimi bilmiyorum.

25.Dünyayla bağlantım kopmuş gibi hissediyorum.

26.Şu anda zaman yavaş geçiyormuş gibi hissediyorum.

27.Etrafimdaki insanlara sinir oluyorum.

28.Öylece oturup bir şeyler olsun diye bekliyormuşum gibi hissediyorum.

29.Çevremde konuşabileceğim kimse yokmuş gibi hissediyorum.

\section{REFERENCES}

Ahmed, S. M. S. (1990). Psychometric properties of the poredom proneness scale. Perceptual and Motor Skills, 71, 963-966.

Alda, M., Minguez, J., Montero-Marin, J., Gili, M., Puebla-Guedea, M., HerreraMercadal, P., Navarro-Gil, M., Garcia-Campayo, J. (2015). Validation of the Spanish version of the Multidimensional State Boredom Scale (MSBS). Health and Quality of Life Outcomes, 13, 59. doi: 10.1186/s12955-015-0252-2.

Barnett, L.A., Klitzing, S.W.(2006). Boredom in free time: Relationships with personality, affect, and motivation for different gender, racial and ethnic student groups. Leisure Sciences, 28(3), 223-244.

Belton T, Priyadharshini E. (2007). Boredom and schooling: A crossdisciplinary exploration. Cambridge Journal of Education, 37(4), 579-595.

Büyüköztürk, Ş. (2007). Sosyal bilimler için veri analizi el kitabı. Ankara: Pegem Akademik Yayıncilık. 
Dursun, P., Tezer, E. (2013). Turkish adaptation of the boredom proneness scale shortform. Procedia-Social and Behavioral Sciences, 84, 1550-1554.

Eastwood, J. D., Cavaliere, C., Fahlman, A. A., Eastwood, A. E. (2007). A desire for desires: Boredom and its relation to alexithymia. Personality and Individual Differences, 42, 1035-1045.

Fahlman, S.A., Mercer-Lynn, K. B., Flora, D.B., \& Eastwood, J.D. (2013). Development and validation of the multidimensional state boredom scale. Assessment, 20 (1), 68-85. doi: 10.1177/1073191111421303.

Iso-Ahola SE, \& Crowley ED.(1991). Adolescent substance abuse and leisure boredom. Journal of Leisure Research, 23(3), 260-271.

Iso-Ahola, S.E., \& Weissinger, E. (1990). Perceptions of boredom in leisure: Conceptualization, reliability and validity of the leisure boredom scale. Journal of Leisure Research, 22(1), 1-17.

Kara, F.M, Gürbüz, B., Öncü, E. (2014). Leisure Boredom Scale: The factor structure and the demographic differences. Turkish Journal of Sport and Exercise, 16 (2), 28-35.

Kılıç, H.E., Şen, A.İ. (2014). Turkish adaptation study of UF/EMI critical thinking disposition instrument. Education and Science, 39 (176), 1-12.

Lee, T. W. (1986). Toward the development and validation of a measure of job boredom. Manhattan College Journal of Business, 15, 22-28.

LePera, N. (2011). Relationships between boredom proneness, mindfulness, anxiety, depression, and substance use. New School Psychology Bulletin, 8, 15-25.

Lin CH, Lin SL, Wu CP. (2009). The effects of parental monitoring and leisure boredom on adolescents' internet addiction. Adolescence, 44(176), 993-1004.

MacDonald, D.A., Holland, D. (2002). Spirituality and boredom proneness. Personality and Individual Differences, 32, 1113-1119.

Mann, S., Robinson, A. (2009). Boredom in the lecture theatre: an investigation into the contributors, moderators, and outcomes of boredom amongst university students. British Educational Research Journal, 35 (2), 243-258.

Mercer, K.B., \& Eastwood, J.D. (2010). Is boredom associated with problem gambling behaviour? It depends on what you mean by "boredom." International Gambling Studies. 10, 91-104. doi: 10.1080/14459791003754414.

Mercer-Lynn, K.B., Flora, D.B., Fahlman, S.A., \& Eastwood, J.D. (2011). The measurement of boredom: Differences between existing self-report scales. Assessment, $20(5), 585-96$. 
Patterson I. R., Pegg, S., \& Dobson-Patterson, R. (2000). Exploring the links between leisure boredom and alcohol use among youth in rural and urban areas of Australia. Journal of Park and Recreation Administration, 18(3), 53-75.

Ragheb, M. G., \& Merydith, S. P. (2001). Development and validation of a unidimensional scale measuring free time boredom. Leisure Studies, 20, 41-59.

Shaw, S.M. (1996). Boredom, stress and social control in the daily activities of adolescents. Journal of Leisure Research, 28(4), 274-293.

Vodanovich, S. J., \& Kass, S. J. (1990). A factor analytic study of the boredom broneness scale. Journal of Personality Assessment, 55, 115, 123.

Vodanovich, S.J., Watt J.D. (1999). The relationship between time structure and boredom proneness: An investigation between two cultures. Journal of Social Psychology, 139(2), 143- 152.

Vodanovich, S. J. (2003). Psychometric measures of boredom: A review of the literature. The Journal of Psychology, 137, 569595.

Vodanovich, S. J., Wallace, J. C., Kass, S. J. (2005). A confirmatory approach to the factor structure of the boredom proneness scale: Evidence for a two-factor short form. Journal of Personality Assessment, 85, 295-303.

Watt, J. D., \& Ewing, J. E. (1996). Toward the development and validation of a measure of sexual boredom. Journal of Sex Research, 33, 57-66.

Watt, J.D., Vodanovich, S.J. (1999). Boredom proneness and psychosocial development. The Journal of Psychology, 133 (3), 303-314.

Wegner L, Flisher, AJ. (2009). Leisure boredom and adolescent risk behavior: a systematic literature review. Journal of Child and Adolescent Mental Health, 21(1), 128.

Wegner L, Flisher AJ, Muller M, Lombard C. (2006). Leisure boredom and substance use amongst high school students in South Africa. Journal of Leisure Research, 22(3), 228-243.

Weissinger, E. (1995). Effects of boredom on self-reported health. Society and Leisure, 18(1), 21-32. 
Figure 1. Path Analysis results of CFI I.

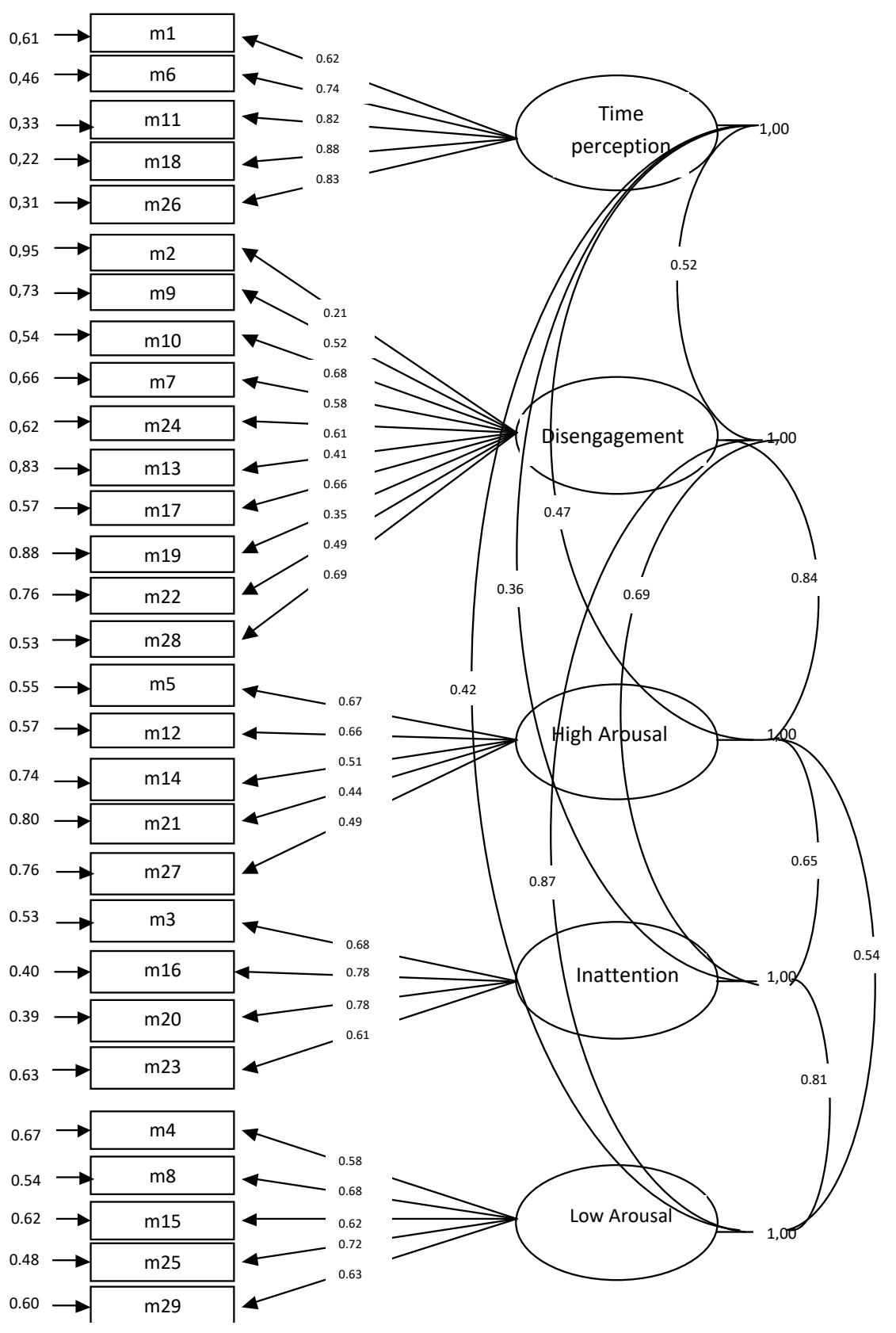


Figure 2. Path Analysis results of CFI II.

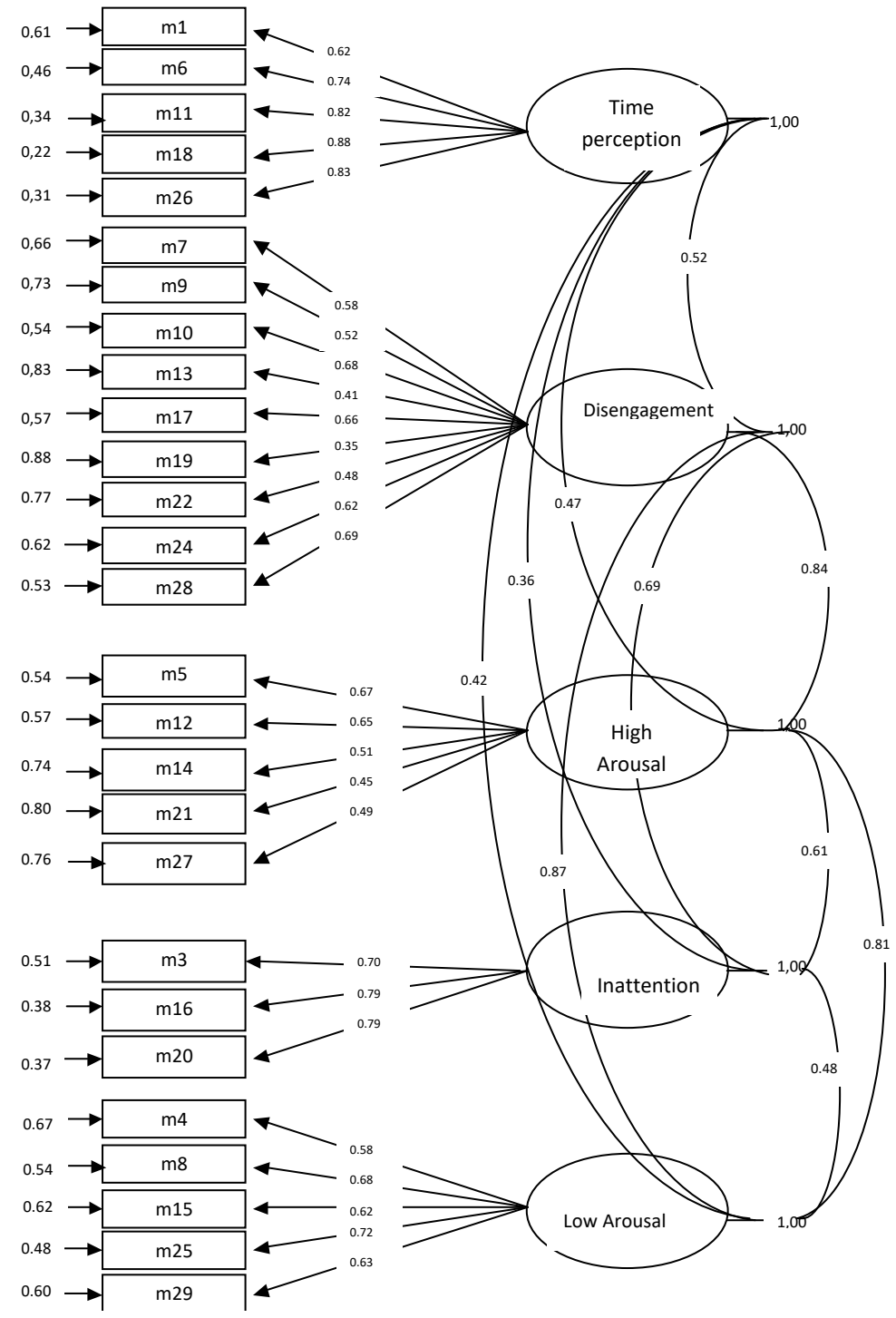




\section{UZUN ÖZET}

Can sıkıntısı tüm toplumlarda yaygın olarak deneyimlenen bir problemdir. Türkiye'de tüm yaş gruplarında görülmektedir. Can sıkıntısının ciddi psikolojik problemlere yol açıı̆ı, okulu bırakma, kumara yönelme, depresyon ve yeme bozukluklarına yol açabilmektedir (Eastwood, Cavaliere, Fahlman, \& Eastwood, 2007; Mann \& Robinson, 2009; Mercer \& Eastwood, 2010; LePera, 2011).

Bu çalışmanın amacı Fahlman, Mercer-Lynn, Flora and Eastwood (2013) tarafindan geliştirilen Çok boyutlu Can Sıkıntısı Eğilimi Ölçeğini Türkçe'ye uyarlamaktır. Ölçek maddelerinin çevirme-geri çevirme yöntemi ile çevirisi yapıldıktan sonra çevrimiçi olarak oluşturulan ölçek önce pilot çalışma için 42 öğrenciye uygulanmış ve görüş ve önerileri alınmış, Cronbach Alfa güvenirlik katsayısı .91 bulunmuştur.

Ölçek Afyon Kocatepe Üniversitesi’nde eğitim gören 305 öğrenciye uygulanmıştır. Yüz yirmi sekiz erkek ve 177 kadın katılımcı; İktisat İşletme (\% 28.2), Uluslararası Ticaret ve Finansman (\% 46.9), Mühendislik (\% 4.6) ve diğer (\% 1.6) bölümlerde öğrenim görmektedir. Katılımcılar \% 9.8 hazırlık sinıfinda, \% 50.2 birinci sınıfta, \% 1.2 ikinci sınıfta, \% 1 üçüncü sinıfta, \% 36.1 son sinıfta ve \% 1.3 ise beşinci yıldır öğrenimine devam etmekte olan öğrencilerdir. 18 Katılımcı Karadeniz, 104 Ege, 34 Akdeniz, 62 Marmara, 60 İç Anadolu, 7 Doğu Anadolu, 16 Güneydoğu Anadolu bölgelerinden ve 4 diğer ülkelerdendir.

Doğrulayıcı Faktör Analizi sonuçlarına göre ölçeğin 29 maddesinden iki tanesi çıkarılmıştır. Bu maddelerden Madde 2 düşük faktör yüküne (.21) sahipti. Madde 23 ise modifikasyon indeksine göre İlişki Kesme, Yüksek Uyarılma ve Düşük Uyarılma altfaktörlerinin üçü ile de ilişkilendirildiğinde Chi-square değerinde sırası ile 28.6, 26.2 ve 35.0 miktarlarında düşme olacağını belirtmekteydi. Bu sebeplerle Madde 2 ve 23 ölçekten çıkarılmış ve toplamda 27 madde olarak psikometrik değerleri tekrar ölçülmüştür.

Ölçeğin yapılan analizler sonucunda 27 madde ve 5 faktör (İlişki Kesme, Yüksek Uyarılma, Düşük Uyarılma, Dikkat Etmemek, Zaman Algısı) olarak kullanılmasına karar verilmiştir. Cronbach Alpha güvenirlik katsayısı İlişki Kesme için .80, Yüksek Uyarılma için .68, Düşük Uyarılma için .78, Dikkat etmemek için .80 ve Zaman Algısı için $.88^{\prime}$ dir. Tukey's Test for Nonadditivity değeri ise .169 olarak bulunmuştur. Tüm ölçek için iç tutarlılık güvenirlik değeri .91 olarak bulunmuştur. 
Çalışma sonuçlarına göre, Çok Boyutlu Can Sıkıntısı Eğilimi Ölçeği’nin Türkçe versiyonunun psikometrik özellikleri bu ölçeğin can sıkıntısı eğilimini ölçmek için kullanılabileceğini göstermiştir. 